\title{
Specialized Outpatient Clinic vs Stroke Unit for TIA and Minor Stroke
}

\section{A Cohort Study}

Sidsel Hastrup, MD, PhD, Soren P. Johnsen, MD, PhD, Martin Jensen, MSc, Paul von Weitzel-Mudersbach, MD, PhD, Claus Z. Simonsen, MD, PhD, Niels Hjort, MD, PhD, Anette T. Møller, MD, PhD, Thomas Harbo, MD, PhD, Marika S. Poulsen, MD, Helle K. Iversen, MD, DMSci, Dorte Damgaard, MD, PhD, and Grethe Andersen, MD, DMSci

Neurology ${ }^{\circledR}$ 2021;96:e1096-e1109. doi:10.1212/WNL.0000000000011453

\section{Abstract}

\section{Objective}

To evaluate the effects of an outpatient clinic setup for minor stroke/TIA using subsequent admission of patients at high risk of recurrent stroke.

\section{Methods}

We performed a cohort study of all patients with suspected minor stroke/TIA seen in an outpatient clinic at Aarhus University Hospital, Denmark, between September 2013 and August 2014. Patients with stroke were compared to historic (same hospital) and contemporary (another comparable hospital) matched, hospitalized controls on nonprioritized outcomes: length of stay, readmissions, care quality (10 process-performance measures), and mortality. Patients with TIA were compared to contemporary matched, hospitalized controls. Following complete diagnostic workup, patients with stroke/TIA were classified into low/high risk of recurrent stroke $\leq 7$ days.

\section{Results}

We analyzed 1,076 consecutive patients, of whom 253 (23.5\%) were subsequently admitted to the stroke ward. Stroke/TIA was diagnosed in 215/171 patients, respectively. Fifty-six percent $(121 / 215)$ of the patients with stroke were subsequently admitted to the stroke ward. Comparison with the historic stroke cohort $(n=191)$ showed a shorter acute hospital stay for the strokes (median 1 vs 3 days; adjusted length of stay ratio 0.49 ; 95\% confidence interval $0.33-0.71$ ). Thirty-day readmission rate was $3.2 \%$ vs $11.6 \%$ (adjusted hazard ratio 0.23 [0.09-0.59]), and care quality was higher, with a risk ratio of 1.30 (1.15-1.47). The comparison of stroke and TIAs to contemporary controls showed similar results. Only one patient in the low risk category and not admitted experienced stroke within 7 days $(0.6 \%)$.

\section{Conclusions}

An outpatient clinic setup for patients with minor stroke/TIA yields shorter acute hospital stay, lower readmission rates, and better quality than hospitalization in stroke units.

\section{Classification of Evidence}

This study provides Class III evidence that a neurovascular specialist-driven outpatient clinic for patients with minor stroke/TIA with the ability of subsequent admission is safe and yields shorter acute hospital stay, lower readmission rates, and better quality than hospitalization in stroke units.

From the Danish Stroke Centre, Neurology (S.H., P.v.W.-M., C.Z.S., N.H., A.T.M., T.H., M.S.P., D.D., G.A.), Aarhus University Hospital; Department of Clinical Medicine, Health (S.H. C.Z.S., N.H., G.A.), Aarhus University; Danish Center for Clinical Health Services Research, Department of Clinical Medicine (S.P.J., M.J.), Aalborg University; Stroke Centre Rigshospitalet, Department of Neurology (H.K.I.), Rigshospitalet; and Faculty of Health and Medical Sciences (H.K.I.), University of Copenhagen, Denmark.

Go to Neurology.org/N for full disclosures. Funding information and disclosures deemed relevant by the authors, if any, are provided at the end of the article. The Article Processing Charge was funded by the University of Aarhus, Denmark; the Lundbeck Foundation, Denmark; and the Laerdal Foundation, Norway. 


\section{Glossary}

CDR = Central Denmark Region $; \mathbf{C I}=$ confidence interval; DSR = Danish Stroke Registry; DWI = diffusion-weighted imaging; HR = hazard ratio; ICH = intracerebral hemorrhage; LOSR = length of stay ratio; NIHSS = NIH Stroke Scale; RR = risk ratio; SSS $=$ Scandinavian Stroke Scale.

Patients with minor stroke/TIA are at high risk of a recurrent ischemic event, ${ }^{1,2}$ but landmark studies show a dramatic effect of immediate hospital referral. ${ }^{3,4}$ It has long been known that patients in an organized inpatient stroke unit fare better than those in a general ward, ${ }^{5,6}$ and it is feasible and cost-effective to handle most minor strokes and TIAs in specialized acute outpatient clinics. ${ }^{4,-11}$ However, we do not know how acute outpatient specialist care compares with in-hospital stroke unit care. ${ }^{12,13}$ It is debated how to most efficiently organize services for patients with minor stroke/TIA ${ }^{12,14-16}$ and use of hospitalization seems widespread. ${ }^{17,18}$ Hospitalization confers theoretical benefits over urgent outpatient clinic referral including monitoring of the patients and rapid access to revascularization, but these benefits are offset by potential drawbacks of hospitalization together with potential overuse of hospital resources. ${ }^{12,14,19,20}$ The risk of a recurrent stroke remains the main concern of outpatient treatment and an innovative approach may be a hybrid that combines benefits from both strategies. ${ }^{14}$

In 2012, an acute outpatient clinic for patients with suspected minor stroke/TIA opened at Aarhus University Hospital, Denmark, following centralization of acute stroke care services. ${ }^{21,22}$ In the clinic, a specialized neurovascular team performs a complete diagnostic workup and treatment the same day the patient is referred and assesses the risk of patients with stroke/TIA to identify those at high risk of a recurrent stroke and hence eligible for admission to a regular stroke ward.

\section{Methods}

\section{Standard Protocol Approvals, Registrations, and Patient Consents}

The study was approved by the Danish Data Protection Agency (2012-58-006), the Danish Patient Safety Authority (3-3013-1878/1), and the Danish Clinical Registries. Under Danish law, registry-based studies require no ethics approval or patient consent. The Danish Patient Safety permitted collection of information from the patient records without patients' consent.

\section{Primary Research Question and Classification of Level of Evidence}

The primary research question was as follows: Is an outpatient clinic setup for patients with minor stroke/TIA combined with admission of selected high risk patients effective and safe compared to stroke unit admission of all patients with minor stroke/TIA?
This study provides Class III evidence that an outpatient clinic setup for minor stroke/TIA with subsequent admission of patients at high risk of a recurrent stroke yields shorter acute hospital stay, lower readmission rates, and better quality than hospitalization in stroke units.

\section{Outpatient Clinic Setup and Risk Assessment}

The outpatient clinic at Aarhus University Hospital, Denmark, is part of 1 of the 2 high-volume designated stroke centers that receive all patients with acute stroke and TIA from the Central Denmark Region (CDR) (1.3 million inhabitants). ${ }^{22}$ The outpatient clinic is an integrated part of the stroke unit, which is open 7 days a week in the daytime (8 AM-6 PM) and staffed by a specialized neurovascular senior doctor, a nurse, and therapists when needed.

A local stroke guideline was developed for all patients with suspected acute stroke and TIA with symptom onset within the past 7 days and 48 hours, respectively, or accumulated neurovascular episodes. According to this guideline, the prehospital service or general practitioners immediately called an experienced neurologist on call 24 hours/7 days to arrange acute evaluation by stroke specialist. All self-reliant patients with suspected acute minor stroke who were not candidates for acute reperfusion or TIA were seen in the outpatient clinic during opening hours. At nighttime, these patients were admitted for immediate evaluation in the stroke unit. The emergency department was bypassed in all cases. Figure 1 shows the details of the patient flow.

Diagnostic workup in the outpatient clinic included a brain scan (standard MRI), ultrasound of carotid arteries (if indicated, ultrasound, CT angiography, or magnetic resonance angiography of the intracranial vessels), blood samples, ECG, and evaluation of lifestyle factors. If a Holter monitor was indicated, the patient was provided one as an outpatient and could return the equipment by mail. If the patient needed echocardiography, he or she was referred to the Department of Cardiology. All patients in need of outpatient rehabilitation had a full evaluation by a physiotherapist and an occupational therapist before returning home, and had a plan for outpatient rehabilitation by community service. Patients in whom thrombolysis or thrombectomy was indicated were handed over to staff in the stroke unit as the outpatient clinic was part of the acute stroke center and located in the same facilities.

After the outpatient evaluation, we systematically assessed risk in all patients diagnosed with stroke or TIA to distinguish 
Figure 1 Details of the Triage of Patients With Suspected Stroke/TIA (Symptom Onset $<7$ Days/48 Hours) in the Central Denmark Region in the Study Period

Suspected stroke/TIA

EMS or GP immediately call
experienced neurologist
(on call 24/7)

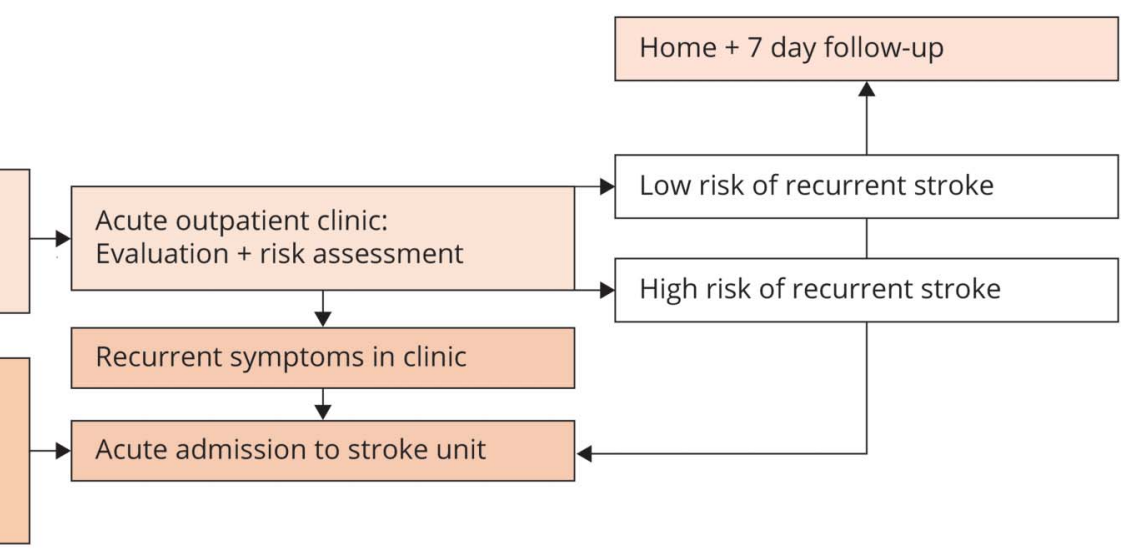

Suspected minor stroke/TIA without need of a hospital bed and referred day time

Suspected stroke/TIA (including candidates for revascularization) with need of a bed or referred night time

Stroke/TIA not suspected after evaluation by experienced neurologist

Emergency department or others

$\mathrm{EMS}=$ emergency medical services; GP = general practitioner .

between those at low risk of a recurrent stroke within 7 days who could safely be sent directly home from those at high risk of a recurrent stroke who may need to be admitted to the stroke ward. For risk assessment, we used a tool developed by the neurovascular team. The tool included the ABCD2 score ${ }^{23-25}$ and results of imaging of the brain and precranial or intracranial arteries ${ }^{26,27}$ together with other risk factors, for example, cardioembolic risk factors. At the neurologist's discretion, other elements like psychosocial issues were taken into account. For patients with stroke, the tool included the $\mathrm{NIH}$ Stroke Scale (NIHSS) score ${ }^{28}$ instead of the ABCD2 score. The risk assessment was a guiding tool only; the final decision to admit the patient to the stroke unit was made at the specialized neurovascular senior doctor's discretion.

If the patient with stroke/TIA was sent home directly from the outpatient clinic, we rang the patient on day 7 to identify any new vascular events.

In patients without a cerebrovascular diagnosis, staff in the outpatient clinic finished the diagnostic workup, performing other relevant tests or procedures, for example, lumbar puncture or other neuroradiologic examinations. The patient was admitted to the general neurologic ward for further investigations only in case of a suspected or confirmed major neurologic disease (e.g., tumor). Furthermore, we assessed patients with non-neurologic disease to determine whether they needed admission at another hospital department or could be sent home to follow up with a general practitioner.

\section{Study Design}

This was a cohort study. The effects of the outpatient clinic setup in patients with minor stroke/TIA were investigated by comparing outcomes to those of matched controls.

\section{Study Cohort and Matched Controls}

The outpatient clinic cohort included all patients with suspected minor stroke or TIA evaluated in the acute neurovascular outpatient clinic at Aarhus University Hospital, Denmark, between 1 September 2013 and 31 August 2014, including patients who ended up being admitted at the stroke ward or converted to an IV thrombolysis pathway.

Patients with minor strokes were compared to 2 reference populations, including historic and contemporary matched, hospitalized controls, respectively. Patients with TIA were compared to contemporary matched, hospitalized controls only as historic controls were not available in the Danish Stroke Registry (DSR).

Figure 2 shows the details of how we generated the matched historic stroke cohort from the same hospital between May 2011 and April 2012, that is, before the outpatient clinic was established, and the contemporary stroke and TIA cohort from a comparable stroke center at a university hospital in the Capital Region (Glostrup) without an acute outpatient clinic service. Before matching the 2 cohorts, we restricted the patient populations to patients with reliable data on length of acute hospital stay, known vital status, and complete 
Figure 2 Details of Generation of the Matched Historic Stroke Cohort and the Matched Contemporary Stroke and TIA Cohorts

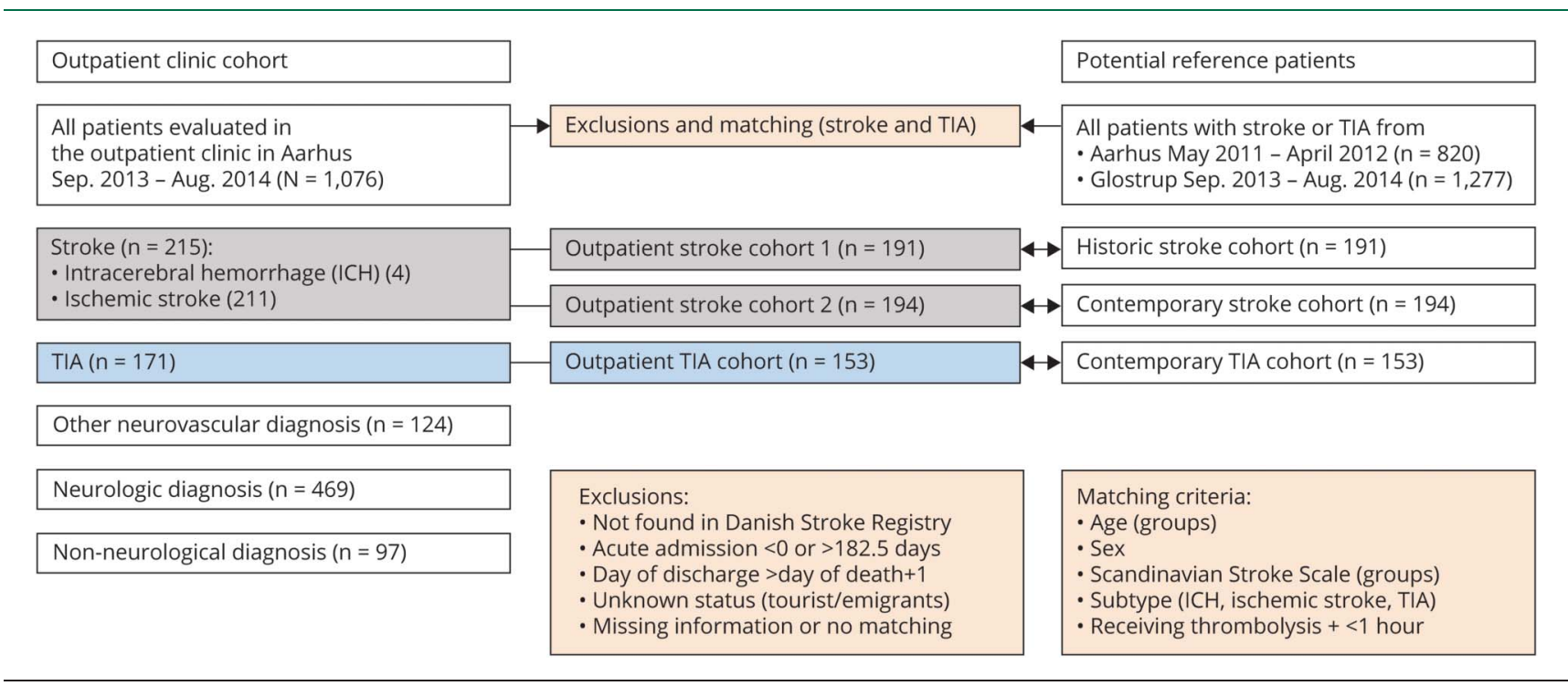

information on matching criteria: age (groups: $0-18,19-50$, 51-65, 66-80, 80+ years), sex, stroke severity (Scandinavian Stroke Scale [SSS] in groups: 0-14, 15-29, 30-44, 45-58), treatment with thrombolysis including door-to-needle time (under or above 1 hour), and subtype of diagnosis (ischemic stroke, ICH, or TIA). The matching was done 1:1, and patients from the reference cohorts could be used more than once.

\section{Outcomes}

The complete study cohort was investigated with regards to the distribution of "neurovascular diagnosis," "neurologic diagnosis," and "non-neurologic diagnosis," and the most common diagnoses within each subgroup were identified. Furthermore, we estimated the rates of patients with subsequent admission at the stroke ward. In patients with ischemic stroke/TIA, we estimated the rates of low risk and high risk according to the risk assessment tool. The rate of recurrent vascular events within 7 days was examined in patients with stroke or TIA discharged directly from the outpatient clinic.

The effects of the outpatient clinic setup were investigated in patients with stroke using the following nonprioritized outcome measures: length of acute and total (including inhospital rehabilitation) hospital stay, all-cause bed days, hospital readmissions after discharge (0-30 and 31-365 days), mortality ( $0-30$ and $0-365$ days), and quality of care (10 individual key process performance measures).

The patients with TIA were evaluated according to the same outcome measures except for readmissions and all-cause bed days as these data were not available and only 4 of the individual key process performance measures were found to be relevant for TIA and were therefore included.
We defined 2 composite measures of process quality of care: the "all or none" measure was defined as the proportion of minor stroke/TIA episodes where all eligible measures were fulfilled for the individual patient, whereas the "opportunitybased" score was defined as the overall proportion of fulfilled relevant performance measures for each patient. The latter score was calculated by dividing the total number of received processes for each patient by the total number of processes for which the patient was considered eligible.

We recorded the number of patients with TIA with acute lesions on MRI (diffusion-weighted imaging [DWI]positive) or infarction on CT.

\section{Definitions}

A suspected acute stroke (or TIA) was defined as acute focal neurologic deficits (or a history of such disease) with no other obvious reasons than a possible cerebrovascular event. Stroke was defined as symptoms of vascular origin lasting 24 hours or longer or leading to death, and included ischemic strokes and intracerebral hemorrhages (ICH). TIA was defined as a transient episode of neurologic symptoms of ischemic origin lasting less than 24 hours, disregarding MRI confirmation, but TIA did not include related syndromes, for example, amaurosis fugax.

Admission length was counted as half rather than whole days when a patient died or went home from the hospital on the day of evaluation. To ensure that the total length of the hospital stay included rehabilitation irrespective of local organizational differences, admissions on the day following the end of the acute stay were calculated as part of the total stay.

All-cause bed days were defined as the total number of days spent in the hospital within the first year, including the total hospital stay of the initial stroke admission. To ensure that outpatient visits 
Table 1 Risk Category on all Patients With Ischemic Stroke and TIA From the Outpatient Clinic Cohort and Information on Any Subsequent Admission to the Stroke Ward, n (\%)

\begin{tabular}{lll}
\hline $\begin{array}{l}\text { Ischemic stroke and TIA, } \\
\mathbf{n = 3 8 2}\end{array}$ & $\begin{array}{l}\text { High-risk } \\
\text { category, } \mathbf{n = 1 6 7}\end{array}$ & $\begin{array}{l}\text { Low-risk category, } \\
\mathbf{n}=\mathbf{2 1 5}\end{array}$ \\
\hline Admitted to stroke ward & $122(73.1)$ & $45(20.9)$ \\
\hline Stayed as outpatient & $45(26.9)$ & $170(79.1)$ \\
\hline $\begin{array}{c}\text { 7-day follow-up: } \\
\text { recurrent events }\end{array}$ & $1(2.2)^{\mathrm{b}}$ & $1(0.6)^{\mathrm{c}}$ \\
\hline
\end{tabular}

${ }^{a}$ Results of 7-day follow-up for recurrent vascular events (recurrent TIA, stroke, or acute myocardial infarction) in the outpatients without admission to stroke ward.

${ }^{\mathrm{b}}$ Recurrent TIA.

${ }^{\text {' } R e c u r r e n t ~ i s c h e m i c ~ s t r o k e . ~}$

were not counted as part of all-cause bed days, only new admissions (acute/nonacute) of $\geq 24$ hours were included.

To be considered a readmission, at least 1 day was required between the day of the termination of the total stay and the next admission date. Only acute admissions $\geq 24$ hours were included; hence, no outpatient visits were considered readmissions. All admissions due to carotid artery surgery were excluded as readmissions because they were considered part of the acute stroke care.

To be classified as being at low risk, patients with TIA would have to have no acute ischemia on MRI (DWI/infarction on $\mathrm{CT}$ ) or an $\mathrm{ABCD} 2$ score $\leq 3$ and patients with stroke an NIHSS score $<5$. Furthermore, patients with TIA and stroke should have no symptomatic stenosis $(\geq 50 \%)$ of the carotid arteries, no symptomatic stenosis (verified or suspected) of the intracranial vessels, no major cardioembolic risk factors, and no other complications for which an inpatient course was needed.

\section{Data Sources}

A local registry holds information on diagnosis for all patients (vascular or nonvascular), including imaging and risk assessment, and it includes the mandatory process and outcome indicators collected in the DSR. ${ }^{29,30}$ This local registry includes results of 7-day follow-up. Local registration was completed on a daily basis by the clinic's neurovascular team. The electronic medical records were searched in case of missing information on risk assessment or vascular events within 7 days.

We obtained data from the DSR (baseline characteristics, length of acute hospital stay, and process performance measures) to characterize strokes and TIA from the study cohort and the matched cohorts. Reporting to the DSR is mandatory for all acute strokes ( $\geq 18$ years of age) seen at hospitals. Given the Danish tradition for seeing almost all patients with acute stroke symptoms in the hospital, almost all patients with acute stroke in Denmark are registered. ${ }^{31}$ The completeness of stroke event registration in the DSR exceeds $90 \%{ }^{32}$

The Danish National Patient Register provided information on subsequent hospitalizations, including transfers from the acute stroke unit to in-hospital rehabilitation and readmissions. ${ }^{33}$

The Danish Civil Registration System provided information on patients' vital status. ${ }^{34}$ This system assigns a unique personal identification number to all Danish citizens, and we used this to link information recorded in different databases.

\section{Statistical Analysis}

We used a generalized linear model with a log-link and gamma distribution family to compare the length of stay ratios (LOSRs).

For readmissions, we compared hazard ratios (HRs) using multivariable Cox regression encountering the time of a potential readmission or death and analyzed mortality outcomes accordingly. We also calculated adjusted and unadjusted HRs.

We analyzed clinical guideline-recommended process performance measures using binomial regression. Unadjusted risk ratios (RRs) were calculated. We included only cases where the health professionals caring for the individual patient had judged the specific process measure to be relevant.

By using multivariable models, we adjusted for age (continuous variable), living arrangement, previous stroke, diabetes, atrial fibrillation, hypertension, smoking habits, alcohol use, and stroke severity (SSS as a continuous variable). Unknown or missing information on living arrangement, previous stroke, diabetes, atrial fibrillation, hypertension, smoking habits, and alcohol use was encoded by an indicator variable and included in the adjusted analyses. Confidence intervals (CIs) were based on robust standard errors.

We used the Stata 13.0 package (StataCorp LP, College Station, TX) for all analyses.

\section{Data Availability}

According to Danish law, it is not possible to provide public access to a dataset that is based on linkage of data from nationwide public registries. Access to Danish registry data can be granted to individual researchers only upon seeking approval from the National Agency for Data Protection. We therefore cannot place the dataset in a public repository. However, pooling of aggregated data is possible and would be of interest to the research group.

\section{Results}

The outpatient clinic cohort comprised 1,076 patients (figure 2 ), of whom 253 (23.5\%) were subsequently admitted to the stroke unit. A neurovascular diagnosis was given in 510 of the patients (47.4\%). Of these, 215 had a stroke, 171 had TIA, 
Table 2 Characteristics of the Patients From the Matched Cohorts: Outpatient Stroke Cohort 1 (OSC1) vs Historic Stroke Cohort (HSC), Outpatient Stroke Cohort 2 (OSC2) vs Contemporary Stroke Cohort (CSC), and Outpatient TIA Cohort (OTC) vs Contemporary TIA Cohort (CTC)

\begin{tabular}{|c|c|c|c|c|c|c|}
\hline & osc1 & HSC & OSC2 & $\csc$ & OTC & CTC \\
\hline Patients, $\mathrm{n}$ & 191 & 191 & 194 & 194 & 153 & 153 \\
\hline Age, y, mean (SD) & $65.8(11.8)$ & $66.3(13.2)$ & $65.5(12.0)$ & $66.0(12.9)$ & $66.3(13.2)$ & $67.4(13.3)$ \\
\hline Sex, female, $\mathrm{n}(\%)$ & $76(39.8)$ & $76(39.8)$ & 79 (40.7) & 79 (40.7) & $69(45.1)$ & $69(45.1)$ \\
\hline Severity, SSS score, median (IQR) & $56(3)$ & $55(9)$ & $56(3)$ & $56(5)$ & $58(0)$ & $58(2)$ \\
\hline Thrombolysis, n (\%) & $3(1.6)$ & $3(1.6)$ & $3(1.6)$ & $3(1.6)$ & $0(0.0)$ & $0(0.0)$ \\
\hline Days to evaluation, median (IQR) & $1(2)$ & $1(1)$ & $1(2)$ & $1(2)$ & $0(1)$ & $0(0)$ \\
\hline Unknown/missing, n (\%) & $0(0.0)$ & $2(1.0)$ & $0(0.0)$ & $9(4.6)$ & $0(0.0)$ & $3(2.0)$ \\
\hline \multicolumn{7}{|l|}{ Subtype, n (\%) } \\
\hline Intracerebral hemorrhage & $4(2.1)$ & $4(2.1)$ & $3(1.6)$ & $3(1.6)$ & NA & NA \\
\hline Ischemic stroke & 187 (97.9) & $187(97.9)$ & $191(98.5)$ & $191(98.5)$ & NA & NA \\
\hline TIA & NA & NA & NA & NA & $153(100.0)$ & $153(100.0)$ \\
\hline \multicolumn{7}{|l|}{ Former stroke, n (\%) } \\
\hline Yes & 45 (23.6) & $44(23.0)$ & 45 (23.2) & $45(23.2)$ & $18(11.8)$ & $38(24.8)$ \\
\hline No & $146(76.4)$ & $146(76.4)$ & $149(76.8)$ & $148(76.3)$ & $135(88.2)$ & $115(75.2)$ \\
\hline Unknown/missing & $0(0.0)$ & $1(0.5)$ & $0(0.0)$ & $1(0.5)$ & $0(0.0)$ & $0(0.0)$ \\
\hline \multicolumn{7}{|l|}{ Hypertension, $\mathrm{n}(\%)$} \\
\hline Yes & $115(60.2)$ & $104(54.5)$ & $118(60.8)$ & $106(54.6)$ & $72(47.1)$ & 76 (49.7) \\
\hline No & 75 (39.3) & $82(42.9)$ & 75 (38.7) & $85(43.8)$ & $80(52.3)$ & $77(50.3)$ \\
\hline Unknown/missing & $1(0.5)$ & $5(2.6)$ & $1(0.5)$ & $3(1.55)$ & $1(0.7)$ & $0(0.0)$ \\
\hline \multicolumn{7}{|l|}{ Diabetes, n (\%) } \\
\hline Yes & $23(12.0)$ & $21(11.0)$ & $25(13.0)$ & $26(13.4)$ & $20(13.1)$ & $27(17.7)$ \\
\hline No & $168(88.0)$ & $167(87.4)$ & $169(87.1)$ & $167(86.1)$ & $132(86.3)$ & $126(82.4)$ \\
\hline Unknown/missing & $0(0.0)$ & $3(1.6)$ & $0(0.0)$ & $1(0.5)$ & $1(0.7)$ & $0(0.0)$ \\
\hline \multicolumn{7}{|l|}{ Atrial fibrillation, $\mathrm{n}(\%)$} \\
\hline Yes & $11(5.8)$ & $26(13.6)$ & $11(5.7)$ & $28(14.4)$ & $15(9.8)$ & $16(10.5)$ \\
\hline No & $180(94.2)$ & $163(85.3)$ & $183(94.3)$ & $163(84.0)$ & $138(90.2)$ & $135(88.2)$ \\
\hline Unknown/missing & $0(0.0)$ & $2(1.1)$ & $0(0.0)$ & $3(1.6)$ & $0(0.0)$ & $2(1.3)$ \\
\hline \multicolumn{7}{|l|}{ Alcohol use, n (\%) } \\
\hline$\leq 14(\mathrm{~F}) / 21(\mathrm{M})$ units per week & $161(84.3)$ & $158(82.7)$ & $163(84.0)$ & $154(79.4)$ & $135(88.2)$ & $130(85.0)$ \\
\hline$>14(\mathrm{~F}) / 21(\mathrm{M})$ units per week & $29(15.2)$ & $29(15.2)$ & $30(15.5)$ & $32(16.5)$ & $17(11.1)$ & $18(11.8)$ \\
\hline Unknown/missing & $1(0.5)$ & $4(2.1)$ & $1(0.5)$ & $8(4.1)$ & $1(0.7)$ & $5(3.3)$ \\
\hline \multicolumn{7}{|l|}{ Smoking, n (\%) } \\
\hline Daily & $86(45.03)$ & $74(38.7)$ & $88(45.4)$ & $69(35.6)$ & $29(19.0)$ & $32(20.9)$ \\
\hline Former & $56(29.32)$ & $56(29.3)$ & $56(28.9)$ & $51(26.3)$ & $51(33.3)$ & $57(37.3)$ \\
\hline Never & $49(25.65)$ & $61(31.9)$ & $50(25.8)$ & $61(31.4)$ & $71(46.4)$ & $53(34.6)$ \\
\hline Unknown/missing & $0(0.00)$ & $0(0.00)$ & $0(0.0)$ & $13(6.7)$ & $2(1.3)$ & $11(7.2)$ \\
\hline
\end{tabular}


Table 2 Characteristics of the Patients From the Matched Cohorts: Outpatient Stroke Cohort 1 (OSC1) vs Historic Stroke Cohort (HSC), Outpatient Stroke Cohort 2 (OSC2) vs Contemporary Stroke Cohort (CSC), and Outpatient TIA Cohort (OTC) vs Contemporary TIA Cohort (CTC) (continued)

\begin{tabular}{lllllll}
\hline \multicolumn{1}{l}{ OSC1 } & HSC & OSC2 & CSC & OTC & & \\
\hline Living arrangements, $\mathbf{n}(\%)$ & & & & & \\
\hline Living with someone & $125(65.5)$ & $124(64.9)$ & $127(65.5)$ & $116(59.8)$ & $104(67.9)$ & $94(61.4)$ \\
\hline Living alone & $65(34.0)$ & $66(34.6)$ & $66(34.0)$ & $73(37.6)$ & $49(32.0)$ & $52(34.0)$ \\
\hline Other form & $1(0.5)$ & $1(0.5)$ & $1(0.5)$ & $3(1.6)$ & $0(0.0)$ & $3(2.0)$ \\
\hline Unknown/missing & $0(0.0)$ & $0(0.0)$ & $0(0.0)$ & $2(1.0)$ & $0(0.0)$ & $4(2.6)$ \\
\hline
\end{tabular}

Abbreviations: IQR = interquartile range; SSS = Scandinavian Stroke Scale.

and 124 had another neurovascular diagnosis. Ninety-four (43.7\%) of the patients with stroke and $121(70.8 \%)$ of the patients with TIA were sent directly home from the outpatient clinic; of these, 170 (79.1\%) were considered low-risk patients (table 1). Of the 690 patients with another neurovascular diagnosis $(\mathrm{n}=124)$ (not stroke or TIA) or a nonneurovascular diagnosis $(\mathrm{n}=566), 608(88.1 \%)$ were managed without subsequent admission to the stroke ward.

Of the 124 patients with another neurovascular diagnosis, the 3 most common diagnoses were amaurosis fugax/retinal artery occlusion $(n=65)$, recrudescence of prior stroke $(n=35)$, and subdural hemorrhage $(n=6)$. A large percentage $(43.6 \%)$ were registered with another neurologic diagnosis $(n=469)$ and the 3 most common diagnosis among these were disturbances of skin sensation $(n=112)$, migraine $(n=62)$, and dizziness $(n=$ 57). A non-neurologic diagnosis was given in only 97 (9\%) of the patients from the outpatient clinic cohort and the 3 most common diagnoses were syncope and collapse $(n=21)$, noncentral disorders of vestibular function $(n=12)$, and infections (e.g., cystitis, sinusitis, meningitis) $(n=9)$.

We obtained complete risk assessment score data on all 382 patients with ischemic stroke and TIA from the outpatient clinic cohort. Of the 170 patients at low risk handled as outpatients without subsequent admission to the stroke unit, only one had a recurrent stroke $(0.6 \%)$ within the first 7 days after the outpatient visit (table 1).

Three patients with ischemic stroke from the study cohort received thrombolysis; all 3 were treated within 1 hour from arrival to the outpatient clinic.

Of the patients with TIA, 33 (19.3\%) had an acute lesion on MRI (DWI-positive) or an infarction on CT, whereas this was the case for 187 (88.6\%) of the patients with ischemic stroke.

Approximately $90 \%$ of the patients with stroke and TIA were available for comparison with the matched reference populations after we had excluded those who were not eligible or matched. Figure 2 shows details of generation of the matched historic stroke cohort and the matched contemporary stroke and TIA cohorts.

The baseline characteristics of the matched stroke and TIA cohorts are shown in table 2 . Overall, the groups were well balanced with regard to age (stroke/TIA $\approx 66-67$ years) and stroke severity (stroke $\approx 55-56$ of 58 points on the SSS). The median number of days from symptom onset to admission was the same, with a median of 1 day in the stroke cohorts and 0 days in the TIA cohorts.

Patients with stroke from the study cohort $(\mathrm{n}=191)$ had a shorter risk-adjusted length of acute hospital stay than the historic stroke cohort $(\mathrm{n}=191)$ (median 1 vs 3 days; adjusted LOSR 0.49 [95\% CI 0.33-0.71]) (table 3). Furthermore, the length of total stay including rehabilitation was shorter in the strokes from the study cohort than in the historic cohort (median 1 vs 4 days; adjusted LOSR 0.57 [95\% CI 0.36-0.89]) and all-cause bed days within the first year were fewer (median 2 vs 6 days; adjusted LOSR $0.67[0.46-1.00])$. Moreover, in this comparison of strokes from the outpatient clinic cohort with historic controls, readmission rates within the first 30 days after the initial hospital stay were lower (3.2\% vs $11.6 \%$; adjusted HR 0.23 [0.09-0.59]), whereas risk-adjusted readmission rates between days 31 and 365 were comparable. Mortality rates at day 30 and day 365 were equal and low $(0.0 \%$ vs $0.5 \%$; $2.6 \%$ vs $5.2 \%)$. All or none of 10 process performance measures were higher in the patients with stroke from the outpatient clinic cohort (84.3\%) than among patients with stroke in the historic stroke cohort (64.9\%) with an RR of 1.30 (1.15-1.47) (table 3).

The comparison of the patients with stroke from the outpatient clinic cohort $(\mathrm{n}=194)$ with the patients with strokes from the matched contemporary cohort from Glostrup $(\mathrm{n}=194)$ showed almost the same picture, with a shorter median acute hospital stay ( 1 vs 4 days), fewer readmissions in the first 30 days ( 3.1 vs $11.3 \%)$, comparable mortality rates, and higher all or none of 10 process performance measures (table 4).

Patients with TIA from the outpatient clinic cohort were compared with the matched contemporary TIA cohort from 
Table 3 Differences in Lengths of Hospital Stay, All-Cause Bed Days, Readmissions, Mortality, and Process Performance Measures in Outpatient Stroke Cohort 1 (OSC1) and the Matched Historic Stroke Cohort (HSC)

\begin{tabular}{|c|c|c|c|c|}
\hline \multirow[b]{2}{*}{ Bed days (in hospital) } & \multirow[b]{2}{*}{$\begin{array}{l}\text { Outpatient stroke } 1 \text { (OSC1), } n=191 / 215 \text {, } \\
\text { d, median (IQR) }\end{array}$} & \multirow[b]{2}{*}{$\begin{array}{l}\text { Historic stroke (HSC), } n=191 \text {, } \\
\text { d, median (IQR) }\end{array}$} & \multicolumn{2}{|c|}{ OSC1 vs HSC (Cl) } \\
\hline & & & LOSR & $\begin{array}{l}\text { LOSR, } \\
\text { adjusted }^{\text {a }}\end{array}$ \\
\hline Acute stay & $1.00(1.50)$ & $3.00(4.00)$ & $\begin{array}{l}0.48 \\
(0.32-0.73)\end{array}$ & $\begin{array}{l}0.49 \\
(0.33-0.71)\end{array}$ \\
\hline Total stay & $1.00(2.50)$ & $4.00(6.00)$ & $\begin{array}{l}0.50 \\
(0.32-0.77)\end{array}$ & $\begin{array}{l}0.57 \\
(0.36-0.89)\end{array}$ \\
\hline \multirow[t]{3}{*}{ All-cause bed days in 1 year } & $2.00(7.00)$ & $6.00(12.00)$ & $\begin{array}{l}0.60 \\
(0.42-0.87)\end{array}$ & $\begin{array}{l}0.67 \\
(0.46-1.00)\end{array}$ \\
\hline & & & \multicolumn{2}{|l|}{ OSC1 vs HSC } \\
\hline & $\begin{array}{l}\text { Outpatient stroke } 1 \text { (OSC1), } n=191 / 215, \% \\
(\mathrm{Cl}), \mathrm{n} / \text { total } \mathrm{n}\end{array}$ & $\begin{array}{l}\text { Historic stroke (HSC), } n=191, \%(C l) \\
n / \text { total } n\end{array}$ & $\mathrm{HR}(\mathrm{Cl})$ & $\begin{array}{l}\text { HR, } \\
\text { adjusted }^{a}\end{array}$ \\
\hline $0-30$ days & $3.2(0.6-5.7), 6 / 189$ & $11.6(7.0-16.2), 22 / 190$ & $\begin{array}{l}0.26 \\
(0.11-0.65)\end{array}$ & $\begin{array}{l}0.23 \\
(0.09-0.59)\end{array}$ \\
\hline Admitted to stroke unit & $3.6(0.1-7.1), 4 / 112$ & NA & NA & NA \\
\hline Outpatient course only & $2.6(-1.0-6.2), 2 / 77$ & NA & NA & NA \\
\hline 31-365 days & $28.0(21.6-34.5), 53 / 189$ & 30.7 (24.1-37.3), 58/189 & $\begin{array}{l}0.87 \\
(0.60-1.27)\end{array}$ & $\begin{array}{l}0.87 \\
(0.59-1.31)\end{array}$ \\
\hline Admitted to stroke unit & $26.8(18.5-35.1), 30 / 112$ & NA & NA & NA \\
\hline \multirow[t]{2}{*}{ Outpatient course only } & $29.9(19.4-40.3), 23 / 77$ & NA & NA & NA \\
\hline & & & \multicolumn{2}{|l|}{ OSC1 vs HSC } \\
\hline Mortality & $\begin{array}{l}\text { Outpatient stroke } 1 \text { (OSC1), } n= \\
191 / 215, \%(C l), n / \text { total } n\end{array}$ & $\begin{array}{l}\text { Historic stroke (HSC), } n=191, \%(C l) \\
\text { n/total } n\end{array}$ & $\mathrm{HR}(\mathrm{Cl})$ & $\begin{array}{l}\text { HR, } \\
\text { adjusted }^{a}\end{array}$ \\
\hline 30 days & $0.0(0.0-0.0), 0 / 191$ & $0.5(-0.5$ to 1.6$), 1 / 191$ & NA & NA \\
\hline \multirow[t]{2}{*}{365 days } & $2.6(0.3-4.9), 5 / 191$ & $5.2(2.0$ to 8.4$), 10 / 191$ & $\begin{array}{l}0.49 \\
(0.17-1.43)\end{array}$ & $\begin{array}{l}0.94 \\
(0.26-3.37)\end{array}$ \\
\hline & & & \multicolumn{2}{|l|}{ OSC1 vs HSC } \\
\hline $\begin{array}{l}\text { Process performance } \\
\text { measures }\end{array}$ & $\begin{array}{l}\text { Outpatient stroke } 1 \text { (OSC1), n = 191/215, } \\
\%(\mathrm{Cl}), \mathrm{n} / \text { total } n\end{array}$ & $\begin{array}{l}\text { Historic stroke (HSC), } n=191 \text {, } \\
\%(\mathrm{CI}) \mathrm{n} / \text { total } \mathrm{n}\end{array}$ & $\mathrm{RR}(\mathrm{Cl})$ & $\begin{array}{l}\text { RR, } \\
\text { adjusted }^{a}\end{array}$ \\
\hline All or none ${ }^{b}$ & 84.3 (79.1-89.5), 161/191 & $64.9(58.1-71.8), 124 / 191$ & $\begin{array}{l}1.30 \\
(1.15-1.47)\end{array}$ & NA \\
\hline $\begin{array}{l}\text { Opportunity-based score (\%) } \\
\text { c }\end{array}$ & 96.9 (95.7-98.1), 191/191 & 90.9 (88.6-93.3), 191/191 & $\begin{array}{l}1.07 \\
(1.01-1.12)\end{array}$ & NA \\
\hline $\begin{array}{l}\text { Antiplatelet therapy } \leq 2 \\
\text { days }^{\text {d }}\end{array}$ & $98.8(97.2-100.5), 171 / 173$ & 97.3 (94.7-99.9), 145/149 & $\begin{array}{l}1.02 \\
(1.02-1.02)\end{array}$ & NA \\
\hline $\begin{array}{l}\text { Anticoagulation therapy } \\
\leq 14 \text { days }^{\mathrm{d}}\end{array}$ & $66.7(28.2-105.1), 6 / 9$ & $100.0(100.0-100.0), 9 / 9$ & $\begin{array}{l}0.64 \\
(0.40-1.01)\end{array}$ & NA \\
\hline $\begin{array}{l}\text { Brain imaging (CT or MRI) } \\
\leq 0 \text { days }^{\mathrm{d}}\end{array}$ & 98.4 (96.7-100.2), 188/191 & 93.2 (89.6-96.8), 178/191 & $\begin{array}{l}1.06 \\
(1.01-1.10)\end{array}$ & NA \\
\hline $\begin{array}{l}\text { Imaging of the carotids } \leq 4 \\
\text { days }^{\mathrm{d}}\end{array}$ & 99.4 (98.2-100.6), 168/169 & 91.4 (87.0-95.9), 139/152 & $\begin{array}{l}1.12 \\
(1.06-1.17)\end{array}$ & NA \\
\hline Physiotherapy $\leq 2$ days ${ }^{d}$ & $94.9(91.1-98.6), 129 / 136$ & $89.5(84.5-94.4), 136 / 152$ & $\begin{array}{l}1.06 \\
(0.99-1.13)\end{array}$ & NA \\
\hline $\begin{array}{l}\text { Occupational therapist } \leq 2 \\
\text { days }^{\mathrm{d}}\end{array}$ & 95.7 (92.4-99.1), 135/141 & $90.1(85.3-94.9), 137 / 152$ & $\begin{array}{l}1.06 \\
(1.00-1.13)\end{array}$ & NA \\
\hline Mobilization $\leq 0$ days ${ }^{d}$ & 97.4 (95.0-99.7), 184/189 & 91.9 (88.0-95.9), 171/186 & $\begin{array}{l}1.06 \\
(1.01-1.11)\end{array}$ & NA \\
\hline
\end{tabular}


Table 3 Differences in Lengths of Hospital Stay, All-Cause Bed Days, Readmissions, Mortality, and Process Performance Measures in Outpatient Stroke Cohort 1 (OSC1) and the Matched Historic Stroke Cohort (HSC) (continued)

\begin{tabular}{|c|c|c|c|c|}
\hline \multirow[b]{2}{*}{ Bed days (in hospital) } & \multirow[b]{2}{*}{$\begin{array}{l}\text { Outpatient stroke } 1 \text { (OSC1), } n=191 / 215 \text {, } \\
\text { d, median (IQR) }\end{array}$} & \multirow[b]{2}{*}{$\begin{array}{l}\text { Historic stroke (HSC), } n=191 \text {, } \\
\text { d, median (IQR) }\end{array}$} & \multicolumn{2}{|c|}{ OSC1 vs HSC (Cl) } \\
\hline & & & LOSR & $\begin{array}{l}\text { LOSR, }^{\text {adjusted }} \\
\text { a }^{2}\end{array}$ \\
\hline $\begin{array}{l}\text { Nutrition (assessment) } \leq 2 \\
\text { days }^{d}\end{array}$ & $94.7(91.5-97.9), 179 / 189$ & $91.1(87.0-95.1), 173 / 190$ & $\begin{array}{l}1.04 \\
(0.98-1.10)\end{array}$ & NA \\
\hline $\begin{array}{l}\text { Indirect swallow test } \leq 2 \\
\text { days }^{d}\end{array}$ & $96.8(94.3-99.3), 183 / 189$ & 88.7 (84.1-93.3), 165/186 & $\begin{array}{l}1.09 \\
(1.03-1.16)\end{array}$ & NA \\
\hline $\begin{array}{l}\text { Direct swallow test } \leq 2 \\
\text { days }^{\text {d }}\end{array}$ & 96.3 (93.5-99.0), 180/187 & $89.2(84.8-93.7), 166 / 186$ & $\begin{array}{l}1.08 \\
(1.02-1.14)\end{array}$ & NA \\
\hline
\end{tabular}

Abbreviations: $\mathrm{Cl}$ = confidence interval; $\mathrm{HR}=$ hazard ratio; $\mathrm{IQR}=$ interquartile range; $\mathrm{LOSR}=$ length of stay ratio; $\mathrm{RR}=$ risk ratio.

a Adjusted for age (continuous variable), stroke severity (Scandinavian Stroke Scale; continuous variable), living arrangements, previous strokes, diabetes, atrial fibrillation, smoking, alcohol, and hypertension.

${ }^{b}$ All or none of the 10 process performance measures, defined as the proportion of minor stroke/TIA episodes where all eligible measures were fulfilled for the individual patient.

c Opportunity-based score defined as the overall proportion of fulfilled relevant performance measures for each patient.

${ }^{\mathrm{d}}$ Included in ${ }^{\mathrm{b}}$ all or none and in ${ }^{\mathrm{C}}$ opportunity-based score.

Glostrup. In patients with TIA, the acute and total hospital stays were significantly shorter than in the matched contemporary cohort of patients with TIA. The length of the acute stay was a median of 0.5 days vs 2 days. Mortality rates at day 30 and day 365 were comparable in the 2 TIA cohorts $(0.0 \%$ vs $0.0 \% ; 2.0 \%$ vs $5.9 \%)$. All or none of 4 process performance measures were higher in the patients with TIA from the outpatient clinic cohort (96.7\%) than in the contemporary TIA patients (87.6\%) (table 5).

\section{Discussion}

This prospective cohort study of patients seen in an outpatient clinic for acute minor stroke and TIA using subsequent admission of high-risk patients shows that these patients have a shorter hospital stay, lower rate of readmissions at 30 days, and higher quality of care than patients in matched historic and contemporary cohorts without a similar outpatient service.

Substantially reducing the length of hospital stay may have the untoward consequence of increasing the overall readmission rate, which is a frequently used measure of quality and safety $^{35,36}$ of care, although there is some controversy as to how readmissions should be interpreted. ${ }^{37}$ However, we also observed a lower rate of risk-adjusted readmissions within the first 30 days among patients with stroke in the outpatient clinic cohort. This may be due to overall higher quality of care as evidenced by a decline in the rate of recurrent vascular events and other potential complications. ${ }^{38}$ Another driver of this reduction could be the lesser risk of a hospital-acquired infection. ${ }^{39}$ Furthermore, almost half of the patients with stroke in the outpatient clinic cohort (without an inpatient course) were offered a 7-day follow-up by telephone, which was not standard in hospitalized stroke cohorts, and this initiative may have prevented readmissions but also limits direct comparisons.
Readmission rates among these outpatients (with or without 7-day follow-up) were low and similar, indicating that the effect on the results may have been inconsiderable.

Another potential concern with the shorter length of stay is recurrent neurovascular events at home, the risk of which is highest during the first days. ${ }^{1,12}$ To minimize this problem, we aimed to identify and hospitalize patients at high risk of recurrent episodes and hence extended their length of hospital stay. ${ }^{14}$ To qualify the clinical decision to do so, we developed a risk assessment tool using the $\mathrm{ABCD} 2$ score combined with imaging $^{26}$ and other essential risk factors for recurrent episodes. The ABCD2 score and the later addition of vessel status and brain imaging were originally used to select patients in need of rapid referral to a neurovascular specialist, ${ }^{40}$ but here we used the tool to qualify the decision of need for hospitalization. This approach seemed acceptable and safe as the overall rate of recurrent vascular episodes in patients who were treated in the outpatient clinic without admission was low $(0.9 \%)$, only $0.6 \%$ of low-risk patients, and the recurrence rates were lower than previously reported. ${ }^{1,41,42}$

We were not able to calculate a reliable rate of recurrent stroke in the hospitalized patients of the study cohort or in the reference cohorts as new events in the early phase are not registered in the DSR and we did not perform a 7-day follow-up.

The significantly higher fulfillment of process performance measures in patients with minor stroke and TIA from the outpatient clinic cohort within a defined time frame was surprising. Although the exact driver of this remains unknown, we speculate that it may stem from the standardized setup with rapid asses to MRI, ultrasound, and specialist evaluation.

Considering all of the patients with a final diagnosis of stroke and TIA from the entire stroke center at Aarhus University 
Table 4 Differences in Lengths of Hospital Stay, All-Cause Bed Days, Readmissions, Mortality, and Process Performance Measures in Outpatient Stroke Cohort 2 (OSC2) and the Matched Contemporary Stroke Cohort (CSC)

\begin{tabular}{|c|c|c|c|c|}
\hline \multirow[b]{2}{*}{ Bed days (in hospital) } & \multirow[b]{2}{*}{$\begin{array}{l}\text { Outpatient stroke } 2 \text { (OSC2), } n=194 / 215 \text {, } \\
\text { d, median (IQR) }\end{array}$} & \multirow[b]{2}{*}{$\begin{array}{l}\text { Contemporary (CSC), } n=194 \text {, } \\
\text { d, median (IQR) }\end{array}$} & \multicolumn{2}{|l|}{ OSC2 vs CSC } \\
\hline & & & LOSR (Cl) & $\begin{array}{l}\text { LOSR, }^{\text {LOS }} \\
\text { adjusted }^{a}\end{array}$ \\
\hline Acute stay & $1.00(1.50)$ & $4.00(4.00)$ & $\begin{array}{l}0.32 \\
(0.21-0.48)\end{array}$ & $\begin{array}{l}0.37 \\
(0.25-0.55)\end{array}$ \\
\hline Total stay & $1.00(2.50)$ & $4.00(4.25)$ & $\begin{array}{l}0.74 \\
(0.48-1.12)\end{array}$ & $\begin{array}{l}0.72 \\
(0.49-1.07)\end{array}$ \\
\hline \multirow[t]{3}{*}{ All-cause bed days in 1 year } & $2.00(7.00)$ & $6.00(10.25)$ & $\begin{array}{l}0.76 \\
(0.54-1.07)\end{array}$ & $\begin{array}{l}0.95 \\
(0.66-1.38)\end{array}$ \\
\hline & & & \multicolumn{2}{|l|}{ OSC2 vs CSC } \\
\hline & $\begin{array}{l}\text { Outpatient stroke } 2 \text { (OSC2), n = 194/215, \% } \\
\text { (CI), n/total n }\end{array}$ & $\begin{array}{l}\text { Contemporary (CSC), } n=194, \%(C I) \\
n / \text { total } n\end{array}$ & $\mathrm{HR}(\mathrm{CI})$ & $\begin{array}{l}\text { HR, } \\
\text { adjusted }^{a}\end{array}$ \\
\hline $0-30$ days & $3.1(0.6-5.6), 6 / 192$ & $11.3(6.8-15.8), 22 / 194$ & $\begin{array}{l}0.27 \\
(0.11-0.65)\end{array}$ & $\begin{array}{l}0.37 \\
(0.14-0.95)\end{array}$ \\
\hline Admitted to stroke unit & $3.5(0.1-7.0), 4 / 113$ & NA & NA & NA \\
\hline Outpatient course only & $2.5(-1.0-6.1), 2 / 79$ & NA & NA & NA \\
\hline 31-365 days & $27.6(21.2-34.0), 53 / 192$ & $35.4(28.6-42.2), 68 / 192$ & $\begin{array}{l}0.71 \\
(0.49-1.01)\end{array}$ & $\begin{array}{l}0.73 \\
(0.50-1.07)\end{array}$ \\
\hline Admitted to stroke unit & 25.7 (17.5-33.8), 29/113 & NA & NA & NA \\
\hline \multirow[t]{2}{*}{ Outpatient course only } & 30.4 (20.0-40.7), 24/79 & NA & NA & NA \\
\hline & & & \multicolumn{2}{|l|}{ OSC2 vs CSC } \\
\hline Mortality & $\begin{array}{l}\text { Outpatient stroke } 2 \text { (OSC2), n = 194/215, \% } \\
\text { (CI), n/total } n\end{array}$ & $\begin{array}{l}\text { Contemporary (CSC), } n=194, \%(C I) \\
n / \text { total } n\end{array}$ & $\mathrm{HR}(\mathrm{Cl})$ & $\begin{array}{l}\text { HR, } \\
\text { adjusted }^{a}\end{array}$ \\
\hline 30 days & $0.0(0.0-0.0), 0 / 194$ & $0.0(0.0-0.0), 0 / 194$ & NA & NA \\
\hline \multirow[t]{2}{*}{365 days } & $2.6(3.3-4.8)$ & $5.7(2.4-9.0) 11 / 194$ & $\begin{array}{l}0.45 \\
(0.15-1.28)\end{array}$ & $\begin{array}{l}0.63 \\
(0.20-1.98)\end{array}$ \\
\hline & & & \multicolumn{2}{|l|}{ OSC2 vs CSC } \\
\hline $\begin{array}{l}\text { Process performance } \\
\text { measures }\end{array}$ & $\begin{array}{l}\text { Outpatient stroke } 2 \text { (OSC2), n= 194/215, } \\
\%(\mathrm{CI}), \mathrm{n} / \text { total } n\end{array}$ & $\begin{array}{l}\text { Contemporary (CSC), } n=194 \text {, } \\
\%(\mathrm{Cl}) \mathrm{n} / \text { total } \mathrm{n}\end{array}$ & $\mathrm{RR}(\mathrm{Cl})$ & $\begin{array}{l}\text { RR, } \\
\text { adjusted }^{\text {a }}\end{array}$ \\
\hline All or none ${ }^{b}$ & 84.5 (79.4-89.7), 164/194 & $71.6(65.3-78.0), 139 / 194$ & $\begin{array}{l}1.18 \\
(1.06-1.31)\end{array}$ & NA \\
\hline $\begin{array}{l}\text { Opportunity-based score } \\
(\%)^{\mathrm{c}}\end{array}$ & 97.0 (95.8-98.2), 194/194 & 90.7 (88.0-93.3), 194/194 & $\begin{array}{l}1.07 \\
(1.02-1.13)\end{array}$ & NA \\
\hline $\begin{array}{l}\text { Antiplatelet therapy } \leq 2 \\
\text { days }^{\text {d }}\end{array}$ & $98.9(97.3-100.4), 175 / 177$ & $98.0(95.8-100.3), 149 / 152$ & $\begin{array}{l}1.01 \\
(1.01-1.01)\end{array}$ & NA \\
\hline $\begin{array}{l}\text { Anticoagulation therapy } \\
\leq 14 \text { days }^{d}\end{array}$ & $66.7(28.2-105.1), 6 / 9$ & $100.0(100.0-100.0), 23 / 23$ & $\begin{array}{l}0.64 \\
(0.40-1.01)\end{array}$ & NA \\
\hline $\begin{array}{l}\text { Brain imaging (CT or MRI) } \\
\leq 0 \text { days }^{\mathrm{d}}\end{array}$ & 98.5 (96.7-100.2), 191/194 & 88.1 (83.5-92.7), 170/193 & $\begin{array}{l}1.12 \\
(1.06-1.18)\end{array}$ & NA \\
\hline $\begin{array}{l}\text { Imaging of the carotids } \leq 4 \\
\text { days }^{\mathrm{d}}\end{array}$ & 99.4 (98.3-100.6), 172/173 & 96.8 (94.2-99.3), 179/185 & $\begin{array}{l}1.03 \\
(1.03-1.03)\end{array}$ & NA \\
\hline Physiotherapy $\leq 2$ days $^{d}$ & 94.9 (91.2-98.6), 131/138 & 92.9 (88.1-97.7), 105/113 & $\begin{array}{l}1.02 \\
(0.96-1.09)\end{array}$ & NA \\
\hline $\begin{array}{l}\text { Occupational therapist } \leq 2 \\
\text { days }^{\mathrm{d}}\end{array}$ & 95.8 (92.5-99.1), 137/143 & $94.0(89.7-98.4), 110 / 117$ & $\begin{array}{l}1.02 \\
(0.96-1.08)\end{array}$ & NA \\
\hline Mobilization $\leq 0$ days ${ }^{d}$ & 97.4 (95.1-99.7), 187/192 & 91.4 (87.2-95.6), 159/174 & $\begin{array}{l}1.07 \\
(1.01-1.12)\end{array}$ & NA \\
\hline $\begin{array}{l}\text { Nutrition (assessment) } \leq 2 \\
\text { days }^{\mathrm{d}}\end{array}$ & 94.8 (91.6-98.0), 182/192 & $90.1(85.5-94.6), 154 / 171$ & $\begin{array}{l}1.05 \\
(0.99-1.12)\end{array}$ & NA \\
\hline
\end{tabular}


Table 4 Differences in Lengths of Hospital Stay, All-Cause Bed Days, Readmissions, Mortality, and Process Performance Measures in Outpatient Stroke Cohort 2 (OSC2) and the Matched Contemporary Stroke Cohort (CSC) (continued)

\begin{tabular}{|c|c|c|c|c|}
\hline \multirow[b]{2}{*}{ Bed days (in hospital) } & \multirow[b]{2}{*}{$\begin{array}{l}\text { Outpatient stroke } 2 \text { (OSC2), } n=194 / 215 \text {, } \\
\text { d, median (IQR) }\end{array}$} & \multirow[b]{2}{*}{$\begin{array}{l}\text { Contemporary (CSC), } n=194 \text {, } \\
\text { d, median (IQR) }\end{array}$} & \multicolumn{2}{|c|}{ OSC2 vs CSC } \\
\hline & & & $\operatorname{LOSR}(\mathrm{CI})$ & $\begin{array}{l}\text { LOSR, } \\
\text { adjusted }^{\text {a }}\end{array}$ \\
\hline $\begin{array}{l}\text { Indirect swallow test } \leq 2 \\
\text { days }^{\text {d }}\end{array}$ & 96.9 (94.4-99.4), 186/192 & $84.9(79.5-90.3), 146 / 172$ & $\begin{array}{l}1.14 \\
(1.07-1.22)\end{array}$ & NA \\
\hline $\begin{array}{l}\text { Direct swallow test } \leq 2 \\
\text { days }^{\mathrm{d}}\end{array}$ & 96.3 (93.6-99.0), 183/190 & 84.9 (79.4-90.4), 141/166 & $\begin{array}{l}1.13 \\
(1.06-1.22)\end{array}$ & NA \\
\hline
\end{tabular}

Abbreviations: $\mathrm{Cl}$ = confidence interval; $\mathrm{HR}=$ hazard ratio; $\mathrm{IQR}=$ interquartile range; $\mathrm{LOSR}=$ length of stay ratio; $\mathrm{RR}=$ risk ratio.

${ }^{a}$ Adjusted for age (continuous variable), stroke severity (Scandinavian Stroke Scale; continuous variable), living arrangements, previous strokes, diabetes, atrial fibrillation, smoking, alcohol, and hypertension.

${ }^{\mathrm{b}}$ All or none of the 10 process performance measures defined as the proportion of minor stroke/TIA episodes where all eligible measures were fulfilled for the individual patient.

c Opportunity-based score defined as the overall proportion of fulfilled relevant performance measures for each patient.

${ }^{\mathrm{d}}$ Included in ${ }^{\mathrm{b}}$ all or none and in ${ }^{\mathrm{c}}$ opportunity-based score.

Hospital, approximately $16 \%$ of the patients with stroke and $34 \%$ of the patients with TIA went to the outpatient clinic in the study period (based on reported patients in 2014 to $\operatorname{DSR}^{30}$ ), but we were unable to investigate whether, according to the local instruction, more patients were eligible for the outpatient clinic. However, this is likely to have reduced costs per patient as shorter acute hospital stays for patients with stroke reduce hospital costs overall, ${ }^{43}$ and the outpatient setup is probably also more cost effective. ${ }^{8,15,44}$ Furthermore, the reduction in the rate of readmissions is likely to contribute further to cost reduction. ${ }^{45} \mathrm{Nev}$ ertheless, to make final conclusions on the financial implications, a formal economic evaluation is needed.

Centralization of stroke services resulting in shorter hospital stays is associated with high levels of patient and relative satisfaction and we speculate that this outpatient setup similarly led to increased satisfaction among patients and relatives. ${ }^{46}$

All patients with suspected acute minor stroke and TIA were referred directly to the outpatient clinic for diagnostic workup from emergency medical services and general practitioners. A considerable number were given a non-neurovascular diagnosis $(\approx 53 \%)$. A high rate of minor stroke and TIA misdiagnosis $(\approx 60 \%)$ has been documented in nonspecialized settings. ${ }^{47}$ The result of this is that patients forgo the benefits of timely evaluation and early treatment initiation or are treated unnecessarily. Direct referral saves many people from the debilitating effects of misdiagnosis. ${ }^{47}$

An MRI scan of the brain was standard in the diagnostic workup and could have contributed to the high rate of nonneurovascular diagnoses, as MRI is more sensitive to acute smaller ischemic lesions than a CT scan ${ }^{48}$ and helpful in rejecting a stroke/TIA suspicion.

A strength of this study is that it included all patients seen in the outpatient clinic for a period of 1 year and that a high rate of approximately $90 \%$ of the patients with stroke or TIA were available for comparison with the matched reference populations.
A limitation of the nonrandomized study design is that it carries a risk of confounding, which might have affected the length of hospital stay, all-cause bed days, rate of readmissions, and mortality, but it is unlikely to have affected the quality of care reflected in key process performance indicators due to very explicit inclusion and exclusion criteria used for these indicators. By matching the cohorts on essential criteria and adjusting data, we minimized the risk of confounding. Furthermore, we used 2 different reference cohorts to examine the effect, which strengthened the design.

The study period began 16 months after opening of the outpatient clinic and hence the comparison with the historic controls may be subject to confounding by an underlying calendar time-related trend of improvements in stroke care. We chose this study period because we aimed to examine the fully implemented setup and therefore deliberately did not include the period immediately after the launch of the reorganization. Furthermore, historic controls for patients with TIA were lacking, as registration of patients with TIA in the DSR was not implemented until mid-2013.

The matched cohort from a contemporary period from another hospital was not exposed to these general time trends in care but was vulnerable to local differences between the hospitals that could potentially affect the results. To minimize this risk, we used patients from a comparable university hospital without an acute outpatient clinic in a region that is sociodemographically and healthwise fairly similar ${ }^{49}$ and with the same standards of stroke care according to the DSR. ${ }^{30}$

A randomized controlled experiment where all self-reliant patients suspected of minor stroke and TIA were randomized to either the outpatient clinic or direct hospitalization would have minimized the risk of bias further and would in many ways be the preferred design to study the outpatient setup. This was not an option as the implementation of outpatient clinics was part of the politically decided reorganization of the acute stroke services in 
Table 5 Differences in Lengths of Hospital Stay, Mortality, and Process Performance Measures in the Outpatient TIA Cohort (OTC) and the Matched Contemporary TIA Cohort (CTC)

\begin{tabular}{|c|c|c|c|c|}
\hline \multirow[b]{2}{*}{ Bed days (in hospital) } & \multirow[b]{2}{*}{ OTC, $n=153 / 171, d$, median (IQR) } & \multirow[b]{2}{*}{ CTC, $n=153, d$, median (IQR) } & \multicolumn{2}{|l|}{ OTC vs CTC } \\
\hline & & & $\operatorname{LOSR}(\mathrm{Cl})$ & LOSR, adjusted $^{a}$ \\
\hline Acute stay & $0.50(0.50)$ & $2.00(2.00)$ & $0.35(0.29-0.43)$ & $0.37(0.30-0.45)$ \\
\hline \multirow[t]{2}{*}{ Total stay } & $0.50(0.50)$ & $2.00(3.00)$ & $0.36(0.28-0.45)$ & $0.37(0.29-0.47)$ \\
\hline & & & \multicolumn{2}{|l|}{ OTC vs CTC } \\
\hline Mortality & OTC, $n=153 / 171, \%(C \mathrm{Cl}), \mathrm{n} /$ total $n$ & CTC, $n=153, \%(C l), n /$ total $n$ & $\mathrm{HR}(\mathrm{Cl})$ & HR, adjusted ${ }^{a}$ \\
\hline 30 days & $0.0(0.0-0.0) 0 / 153$ & $0.0(0.0-0.0) 0 / 153$ & NA & NA \\
\hline \multirow[t]{2}{*}{365 days } & $2.0(-0.3-4.2), 3 / 153$ & $5.9(2.1-9.7), 9 / 153$ & $0.32(0.09-1.19)$ & $0.31(0.06-1.62)$ \\
\hline & & & \multicolumn{2}{|l|}{ OTC vs CTC } \\
\hline Process performance measures & OTC, $n=153 / 171, \%(C l), n /$ total $n$ & CTC, $n=153, \%(C l), n /$ total $n$ & $\mathrm{RR}(\mathrm{Cl})$ & RR, adjusted ${ }^{a}$ \\
\hline All or none ${ }^{b}$ & 96.7 (93.9-99.6), 148/153 & $87.6(82.3-92.9), 134 / 153$ & $1.10(1.03-1.18)$ & NA \\
\hline Opportunity-based score (\%) ${ }^{c}$ & 98.3 (96.7-99.8), 153/153 & 95.8 (93.9-97.6), 153/153 & $1.03(0.99-1.07)$ & NA \\
\hline Antiplatelet therapy $\leq 2$ days ${ }^{\mathrm{d}}$ & $98.5(96.5-100.6), 134 / 136$ & $100.0(100.0-100.0), 129 / 129$ & $0.98(0.98-0.98)$ & NA \\
\hline Anticoagulation therapy $\leq 14$ days ${ }^{d}$ & $93.3(79.0-107.6), 14 / 15$ & $100.0(100.0-100.0), 11 / 11$ & $0.89(0.78-1.02)$ & NA \\
\hline Brain imaging (CT or MRI) $\leq 0$ days $^{\mathrm{d}}$ & 97.4 (94.8-99.9), 149/153 & 89.3 (84.3-94.3), 134/150 & $1.09(1.03-1.16)$ & NA \\
\hline Imaging of carotids $\leq 4$ days ${ }^{d}$ & $99.3(97.9-100.7), 143 / 144$ & $97.8(95.4-100.3), 135 / 138$ & $1.02(1.02-1.02)$ & NA \\
\hline
\end{tabular}

Abbreviations: $\mathrm{Cl}=$ confidence interval; $\mathrm{HR}$ = hazard ratio; IQR = interquartile range; LOSR = length of stay ratio; $\mathrm{RR}=$ risk ratio.

${ }^{a}$ Adjusted for age (continuous variable), stroke severity (Scandinavian Stroke Scale; continuous variable), living arrangements, previous strokes, diabetes, atrial fibrillation, smoking, alcohol, and hypertension.

${ }^{b}$ All or none of the 4 process performance measures defined as the proportion of minor stroke/TIA episodes where all eligible measures were fulfilled for the individual patient.

c Opportunity-based score defined as the overall proportion of fulfilled relevant performance measures for each patient.

${ }^{\mathrm{d}}$ Included in ${ }^{\mathrm{b}}$ all or none and in copportunity-based score.

the CDR, and a real-world cohort study using matched cohorts therefore became our design choice. ${ }^{50}$

Overall, the investigated acute outpatient clinic setup for minor stroke and TIA was a hybrid model where specialized neurovascular clinicians diagnosed and assessed the risk of recurrent vascular events to support triage for subsequent admission to the stroke ward. The model was beneficial in terms of reduced length of hospital stay, higher quality of stroke care, and reduced 30-day readmission rates compared to historic and contemporary controls. The triage appears safe with a low rate of recurrent vascular events within the first week after returning home. The study was limited by the nonrandomized design as differences among the study cohorts could affect the comparisons.

\section{Study Funding}

This study was supported by the University of Aarhus, Denmark; the Lundbeck Foundation, Denmark; and the Laerdal Foundation, Norway. The funders had no role in the design and conduct of the study; collection, management, analysis, and interpretation of the data; preparation, review, and approval of the manuscript; or the decision to submit the manuscript for publication.

\section{Disclosure}

S. Hastrup has received a research grant from the University of Aarhus and the Lundbeck Foundation. S.P. Johnsen has received speaker honoraria from Bayer, Bristol-Myers Squibb, Pfizer, and Sanofi; has acted as a consultant for Bayer, BristolMyers Squibb, Pfizer, and Sanofi; and has received research grants from Bristol-Myers Squibb and Pfizer. M. Jensen reports no disclosures. P. von Weitzel-Mudersbach has received travel grants from Rapid-Medical, Stryker, and BoehringerIngelheim. C.Z. Simonsen has received a research grant from Novo Nordisk Foundation. N. Hjort and A.T. Møller report no disclosures. T. Harbo has received speaker honoraria from CSL Behring. M.S. Poulsen reports no disclosures. H.K. Iversen served on the scientific advisory board for Amgen $\mathrm{AB}$, Bristol-Myers Squibb, Boehringer-Ingelheim, and Bayer. D. Damgaard served on scientific advisory boards for Amgen, Astra Zeneca, Bayer, and Boehringer-Ingelheim and has received speaker honoraria from Amgen, Bayer, BoehringerIngelheim, Bristol Myers-Squibb, MSD, and Pfizer. G. Andersen has received speaker honoraria from BoehringerIngelheim. Go to Neurology.org/ $\mathrm{N}$ for full disclosures.

\section{Publication History}

Received by Neurology April 17, 2020. Accepted in final form October 21, 2020. 
Appendix Authors

\begin{tabular}{|c|c|c|}
\hline Name & Location & Contribution \\
\hline $\begin{array}{l}\text { Sidsel Hastrup, } \\
\text { MD, PhD }\end{array}$ & $\begin{array}{l}\text { Aarhus } \\
\text { University } \\
\text { Hospital, } \\
\text { Denmark }\end{array}$ & $\begin{array}{l}\text { Designed and conceptualized } \\
\text { study, obtained the official } \\
\text { approvals, data management } \\
\text { and statistical analysis, } \\
\text { interpreted the data, drafted the } \\
\text { manuscript }\end{array}$ \\
\hline
\end{tabular}

\begin{tabular}{ll}
\hline Soren P. Johnsen, & Aalborg \\
MD, PhD & University, \\
& Denmark
\end{tabular}

Designed and conceptualized study, obtained the official approvals, data management and statistical analysis, interpreted the data, revised the manuscript for intellectual contents

\begin{tabular}{lll}
\hline Martin Jensen, & Aalborg & $\begin{array}{l}\text { Data management and statistical } \\
\text { MSc }\end{array}$ \\
& University, & $\begin{array}{l}\text { analysis, interpreted the data, } \\
\text { revised the manuscript for } \\
\text { intellectual contents }\end{array}$ \\
\hline
\end{tabular}

\begin{tabular}{|c|c|c|}
\hline $\begin{array}{l}\text { Paul von Weitzel- } \\
\text { Mudersbach, } \\
\text { MD, PhD }\end{array}$ & $\begin{array}{l}\text { Aarhus } \\
\text { University } \\
\text { Hospital, } \\
\text { Denmark }\end{array}$ & $\begin{array}{l}\text { Major role in the acquisition of } \\
\text { data, interpreted the data, } \\
\text { revised the manuscript for } \\
\text { intellectual contents }\end{array}$ \\
\hline $\begin{array}{l}\text { Claus Z. } \\
\text { Simonsen, MD, } \\
\text { PhD }\end{array}$ & $\begin{array}{l}\text { Aarhus } \\
\text { University } \\
\text { Hospital, } \\
\text { Denmark }\end{array}$ & $\begin{array}{l}\text { Major role in the acquisition of } \\
\text { data, interpreted the data, } \\
\text { revised the manuscript for } \\
\text { intellectual contents }\end{array}$ \\
\hline $\begin{array}{l}\text { Niels Hjort, MD, } \\
\text { PhD }\end{array}$ & $\begin{array}{l}\text { Aarhus } \\
\text { University } \\
\text { Hospital, } \\
\text { Denmark }\end{array}$ & $\begin{array}{l}\text { Major role in the acquisition of } \\
\text { data, interpreted the data, } \\
\text { revised the manuscript for } \\
\text { intellectual contents }\end{array}$ \\
\hline $\begin{array}{l}\text { Anette T. Møller, } \\
\text { MD, PhD }\end{array}$ & $\begin{array}{l}\text { Aarhus } \\
\text { University } \\
\text { Hospital, } \\
\text { Denmark }\end{array}$ & $\begin{array}{l}\text { Major role in the acquisition of } \\
\text { data, interpreted the data, } \\
\text { revised the manuscript for } \\
\text { intellectual contents }\end{array}$ \\
\hline $\begin{array}{l}\text { Thomas Harbo, } \\
\text { MD, PhD }\end{array}$ & $\begin{array}{l}\text { Aarhus } \\
\text { University } \\
\text { Hospital, } \\
\text { Denmark }\end{array}$ & $\begin{array}{l}\text { Major role in the acquisition of } \\
\text { data, interpreted the data, } \\
\text { revised the manuscript for } \\
\text { intellectual contents }\end{array}$ \\
\hline $\begin{array}{l}\text { Marika S. } \\
\text { Poulsen, MD }\end{array}$ & $\begin{array}{l}\text { Aarhus } \\
\text { University } \\
\text { Hospital, } \\
\text { Denmark }\end{array}$ & $\begin{array}{l}\text { Major role in the acquisition of } \\
\text { data, interpreted the data, } \\
\text { revised the manuscript for } \\
\text { intellectual contents }\end{array}$ \\
\hline $\begin{array}{l}\text { Helle K. Iversen, } \\
\text { MD, DMSci }\end{array}$ & $\begin{array}{l}\text { University of } \\
\text { Copenhagen, } \\
\text { Denmark }\end{array}$ & $\begin{array}{l}\text { Designed and conceptualized } \\
\text { study, interpreted the data, } \\
\text { revised the manuscript for } \\
\text { intellectual contents }\end{array}$ \\
\hline $\begin{array}{l}\text { Dorte Damgaard, } \\
\text { MD, PhD }\end{array}$ & $\begin{array}{l}\text { Aarhus } \\
\text { University } \\
\text { Hospital, } \\
\text { Denmark }\end{array}$ & $\begin{array}{l}\text { Designed and conceptualized } \\
\text { study, major role in the } \\
\text { acquisition of data, interpreted } \\
\text { the data, revised the manuscript } \\
\text { for intellectual contents }\end{array}$ \\
\hline $\begin{array}{l}\text { Grethe } \\
\text { Andersen, MD, } \\
\text { DMSci }\end{array}$ & $\begin{array}{l}\text { Aarhus } \\
\text { University } \\
\text { Hospital, } \\
\text { Denmark }\end{array}$ & $\begin{array}{l}\text { Designed and conceptualized } \\
\text { study, interpreted the data, } \\
\text { revised the manuscript for } \\
\text { intellectual contents, guarantor }\end{array}$ \\
\hline
\end{tabular}

\section{References}

1. Coull AJ, Lovett JK, Rothwell PM. Population based study of early risk of stroke after transient ischaemic attack or minor stroke: implications for public education and organisation of services. BMJ 2004;328:326.

2. Rothwell PM, Warlow CP. Timing of TIAs preceding stroke: time window for prevention is very short. Neurology 2005;64:817-820.

3. Rothwell PM, Giles MF, Chandratheva A, et al. Effect of urgent treatment of transient ischaemic attack and minor stroke on early recurrent stroke (EXPRESS study): a prospective population-based sequential comparison. Lancet 2007;370: $1432-1442$.

4. Lavallee PC, Meseguer E, Abboud $\mathrm{H}$, et al. A transient ischaemic attack clinic with round-the-clock access (SOS-TIA): feasibility and effects. Lancet Neurol 2007;6: 953-960.

5. Stroke Unit Trialists. Organised inpatient (stroke unit) care for stroke. Cochrane Database Syst Rev 2007:CD000197.

6. Cadilhac DA, Kim J, Lannin NA, et al. Better outcomes for hospitalized patients with TIA when in stroke units: an observational study. Neurology 2016;86:2042-2048.

7. von Weitzel-Mudersbach P, Johnsen SP, Andersen G. Low risk of vascular events following urgent treatment of transient ischaemic attack: the Aarhus TIA study. Eur J Neurol 2011;18:1285-1290.

8. O'Brien E, Priglinger ML, Bertmar C, et al. Rapid access point of care clinic for transient ischemic attacks and minor strokes. J Clin Neurosci 2016;23:106-110.

9. Paul NL, Koton S, Simoni M, Geraghty OC, Luengo-Fernandez R, Rothwell PM. Feasibility, safety and cost of outpatient management of acute minor ischaemic stroke: a population-based study. J Neurol Neurosurg Psychiatry 2013;84:356-361.

10. Sanders LM, Srikanth VK, Jolley DJ, et al. Monash transient ischemic attack triaging treatment: safety of a transient ischemic attack mechanism-based outpatient model of care. Stroke 2012;43:2936-2941.

11. Ranta A, Barber PA. Transient ischemic attack service provision: a review of available service models. Neurology 2016;86:947-953.

12. Joundi RA, Saposnik G. Organized outpatient care of patients with transient ischemic attack and minor stroke. Semin Neurol 2017;37:383-390.

13. Ranta A, Alderazi YJ. The importance of specialized stroke care for patients with TIA. Neurology 2016;86:2030-2031.

14. Molina CA, Selim MM. Hospital admission after transient ischemic attack: unmasking wolves in sheep's clothing. Stroke 2012;43:1450-1451.

15. Joshi JK, Ouyang B, Prabhakaran S. Should TIA patients be hospitalized or referred to a same-day clinic? a decision analysis. Neurology 2011;77:2082-2088.

16. Donnan GA, Davis SM, Hill MD, Gladstone DJ. Patients with transient ischemic attack or minor stroke should be admitted to hospital: for. Stroke 2006;37: $1137-1138$

17. Webb A, Heldner MR, Aguiar de Sousa D, et al. Availability of secondary prevention services after stroke in Europe: an ESO/SAFE survey of national scientific societies and stroke experts. Eur Stroke J 2019;4:110-118.

18. George BP, Doyle SJ, Albert GP, et al. Interfacility transfers for US ischemic stroke and TIA, 2006-2014. Neurology 2018;90:e1561-e1569.

19. Cucchiara BL, Kasner SE. All patients should be admitted to the hospital after a transient ischemic attack. Stroke 2012;43:1446-1447.

20. Amarenco P. Not all patients should be admitted to the hospital for observation after a transient ischemic attack. Stroke 2012;43:1448-1449.

21. Douw K, Nielsen CP, Pedersen CR. Centralising acute stroke care and moving care to the community in a Danish health region: challenges in implementing a stroke care reform. Health Policy 2015;119:1005-1010.

22. Hastrup S, Johnsen SP, Terkelsen T, et al. Effects of centralizing acute stroke services: a prospective cohort study. Neurology 2018;91:e236-e248.

23. Johnston SC, Rothwell PM, Nguyen-Huynh MN, et al. Validation and refinement of scores to predict very early stroke risk after transient ischaemic attack. Lancet 2007; 369:283-292.

24. Giles MF, Albers GW, Amarenco P, et al. Addition of brain infarction to the ABCD2 Score (ABCD2I): a collaborative analysis of unpublished data on 4574 patients. Stroke 2010;41:1907-1913.

25. Giles MF, Albers GW, Amarenco P, et al. Early stroke risk and ABCD2 score performance in tissue- vs time-defined TIA: a multicenter study. Neurology 2011;77: $1222-1228$.

26. Merwick A, Albers GW, Amarenco P, et al. Addition of brain and carotid imaging to the $\mathrm{ABCD}(2)$ score to identify patients at early risk of stroke after transient ischaemic attack: a multicentre observational study. Lancet Neurol 2010;9:1060-1069.

27. Eliasziw M, Kennedy J, Hill MD, Buchan AM, Barnett HJ. Early risk of stroke after a transient ischemic attack in patients with internal carotid artery disease. Cmaj 2004; 170:1105-1109.

28. Brott T, Adams HP Jr, Olinger CP, et al. Measurements of acute cerebral infarction: a clinical examination scale. Stroke 1989;20:864-870.

29. Mainz J, Krog BR, Bjornshave B, Bartels P. Nationwide continuous quality improvement using clinical indicators: the Danish National Indicator Project. Int J Qual Health Care 2004;16(suppl 1):i45-50.

30. Johnsen SP, Ingeman A, Hundborg HH, Schaarup SZ, Gyllenborg J. The Danish stroke registry. Clin Epidemiol 2016;8:697-702.

31. Thorvaldsen P, Davidsen M, Bronnum-Hansen H, Schroll M. Stable stroke occurrence despite incidence reduction in an aging population: stroke trends in the Danish monitoring trends and determinants in cardiovascular disease (MONICA) population. Stroke 1999;30:2529-2534.

32. Wildenschild C, Mehnert F, Thomsen RW, et al. Registration of acute stroke: validity in the Danish stroke registry and the Danish national registry of patients. Clin Epidemiol 2013;6:27-36.

33. Schmidt M, Schmidt SA, Sandegaard JL, Ehrenstein V, Pedersen L, Sorensen HT. The Danish National Patient Registry: a review of content, data quality, and research potential. Clin Epidemiol 2015;7:449-490.

34. Pedersen CB, Gotzsche H, Moller JO, Mortensen PB. The Danish Civil Registration System: a cohort of eight million persons. Danish Med Bull 2006;53:441-449.

35. Katzan IL, Spertus J, Bettger JP, et al. Risk adjustment of ischemic stroke outcomes for comparing hospital performance: a statement for healthcare professionals from 
the American Heart Association/American Stroke Association. Stroke 2014;45: 918-944.

Zhong W, Geng N, Wang P, Li Z, Cao L. Prevalence, causes and risk factors of hospital readmissions after acute stroke and transient ischemic attack: a systematic review and meta-analysis. Neurol Sci 2016;37:1195-1202.

37. Oliver D. Readmission rates reflect how well whole health and social care systems function. BMJ 2014;348:g1150.

38. Bray BD, Smith CJ, Cloud GC, et al. The association between delays in screening for and assessing dysphagia after acute stroke, and the risk of stroke-associated pneumonia. J Neurol Neurosurg Psychiatry 2017;88:25-30.

39. Magill SS, Edwards JR, Bamberg W, et al. Multistate point-prevalence survey of health care-associated infections. N Engl J Med 2014;370:1198-1208.

40. Kiyohara T, Kamouchi M, Kumai Y, et al. ABCD3 and ABCD3-I scores are superior to $\mathrm{ABCD} 2$ score in the prediction of short- and long-term risks of stroke after transient ischemic attack. Stroke 2014;45:418-425.

41. Lovett JK, Dennis MS, Sandercock PA, Bamford J, Warlow CP, Rothwell PM. Very early risk of stroke after a first transient ischemic attack. Stroke 2003;34:e138-140.

42. Johnston SC. Short-term prognosis after a TIA: a simple score predicts risk. Cleve Clin J Med 2007;74:729-736.
43. Huang YC, Hu CJ, Lee TH, et al. The impact factors on the cost and length of stay among acute ischemic stroke. J Stroke Cerebrovasc Dis 2013;22:e152-158.

44. Sanders LM, Cadilhac DA, Srikanth VK, Chong CP, Phan TG. Is nonadmission-based care for TIA patients cost-effective? a microcosting study. Neurol Clin Pract 2015;5: 58-66.

45. Arefian H, Heublein S, Scherag A, et al. Hospital-related cost of sepsis: a systematic review. J Infect 2017;74:107-117.

46. Perry C, Papachristou I, Ramsay AIG, et al. Patient experience of centralized acute stroke care pathways. Health Expect 2018;21:909-918.

47. Sadighi A, Stanciu A, Banciu M, et al. Rate and associated factors of transient ischemic attack misdiagnosis. eNeurologicalSci 2019;15:100193.

48. Vert C, Parra-Farinas C, Rovira A. MR imaging in hyperacute ischemic stroke. Eur J Radiol 2017;96:125-132.

49. Henriksen DP, Rasmussen L, Hansen MR, Hallas J, Pottegard A. Comparison of the five Danish regions regarding demographic characteristics, healthcare utilization, and medication use: a descriptive cross-sectional study. PLoS One 2015;10:e0140197.

50. Craig P, Cooper C, Gunnell D, et al. Using natural experiments to evaluate population health interventions: new Medical Research Council guidance. J Epidemiol Community Health 2012;66:1182-1186. 


\section{Neurology}

\section{Specialized Outpatient Clinic vs Stroke Unit for TIA and Minor Stroke: A Cohort Study}

Sidsel Hastrup, Soren P. Johnsen, Martin Jensen, et al.

Neurology 2021;96;e1096-e1109 Published Online before print January 20, 2021

DOI 10.1212/WNL.0000000000011453

This information is current as of January 20, 2021

\section{Updated Information \& Services}

References

Citations

Subspecialty Collections

Permissions \& Licensing

Reprints including high resolution figures, can be found at: http://n.neurology.org/content/96/8/e1096.full

This article cites 49 articles, 26 of which you can access for free at: http://n.neurology.org/content/96/8/e1096.full\#ref-list-1

This article has been cited by 1 HighWire-hosted articles: http://n.neurology.org/content/96/8/e1096.full\#\#otherarticles

This article, along with others on similar topics, appears in the following collection(s):

\section{All Cerebrovascular disease/Stroke}

http://n.neurology.org/cgi/collection/all_cerebrovascular_disease_strok e

All Health Services Research

http://n.neurology.org/cgi/collection/all_health_services_research

Cohort studies

http://n.neurology.org/cgi/collection/cohort_studies

Outcome research

http://n.neurology.org/cgi/collection/outcome_research

Patient safety

http://n.neurology.org/cgi/collection/patient_safety

Information about reproducing this article in parts (figures,tables) or in its entirety can be found online at:

http://www.neurology.org/about/about_the_journal\#permissions

Information about ordering reprints can be found online:

http://n.neurology.org/subscribers/advertise

Neurology ${ }^{\circledR}$ is the official journal of the American Academy of Neurology. Published continuously since 1951, it is now a weekly with 48 issues per year. Copyright Copyright ( 2021 The Author(s). Published by Wolters Kluwer Health, Inc. on behalf of the American Academy of Neurology.. All rights reserved. Print ISSN: 0028-3878. Online ISSN: 1526-632X.

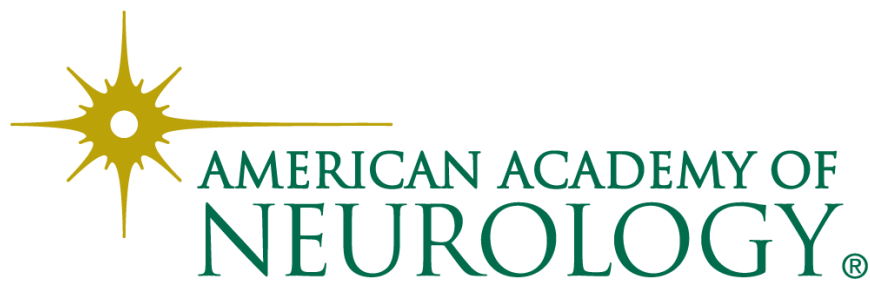

